\title{
A THEOLOGIAN READS THE NEWSPAPER
}

Karl Barth told a reporter that part of his standard advice to young theologians was to "take your Bible and take your newspaper, and read both. But interpret newspapers from your Bible."1 This issue of the journal follows Barth's advice. It has three articles with a theological perspective on front-page, above-the-fold contemporary issues. In our two lead articles, Peter van der Sluijs takes on homelessness in the United Kingdom and Andrew Van Tiem asks whether the retail leviathan Amazon can be classified as an "empire." David Conway, appearing for the second time in these pages, ${ }^{2}$ takes on the thorny problem of "actuarial justice" for troubled minors. ${ }^{3}$

In one way, these are well-hashed topics. Clearly the obligation to the homeless and others in need is, or should be, at the top of every Christian concern. ${ }^{4}$ The short answer to whether Amazon is an empire is "of course it is." After all, Amazon's market capitalization is essentially the same as Russia's gross domestic product, and Russia's imperial ambitions provide a daily topic for Western journalists. But van der Sluijs and Van Tiem don't take the easy path. As the name implies, van der Sluijs's topic is what the homeless can teach the rest of us about our church structures and the theology preached therein. Similarly, Van Tiem doesn't ask whether Amazon is an empire in the generic sense of large and dominant; he crafts a specific definition of empire, based on the $18^{\text {th }}$ Chapter of the Revelation to John, and then does a subtle analysis of how it does and does not qualify.

All three papers draw on A-list theologians. Van der Sluijs relies heavily on Gustavo Gutierrez, Duncan Forrester, and Pope Francis. Conway suggestion of an alternative justice model takes its inspiration from Jurgen Moltmann and Oliver O’Donovan. Van Tiem draws from Richard Bauckham, Néstor Miguez, Walter Brueggemann, and a host of others, as well as prominent nontheological writers such as Soshana Zuboff.

Bringing Oliver O'Donovan into our conversation is especially fortunate. Last month, the School of Divinity proudly hosted Professor O'Donovan as the 2021-2022 Gifford Lecturer, on the topic "The Disappearance of Ethics." The six lectures, which are available on the University's

${ }^{1}$ Time Magazine, May 1, 1966.

2 "Troubled Children," Bible and the Contemporary World, 2:2 (Fall 2020), 298-305.

${ }^{3}$ The reader has probably noticed that our two lead authors share the given names of Jesus's first two apostles, the fisherman brothers Peter and Andrew, and our third the namesake of Israel's greatest king. I for one smile about the coincidence as we approach Christmas.

${ }^{4}$ A Church Urban Fund study cited by Van der Sluijs indicates that " $96 \%$ of respondents agreed that 'as a Christian I believe God calls me to practically respond to poverty and injustice."” 
YouTube channel here, draw from Professor O' Donovan's extraordinary body of work. In Lecture 3, particularly, continuing a theme from Self, World, and Time, ${ }^{5}$ the first volume of his threevolume Ethics as Theology, he proposes that the concept of person itself can only be understood in relation to a community. As he says in Self, World, and Time, drawing on the sixth chapter of Paul's letter to the Galatians, ${ }^{6}$ "a secure sense of 'I,' ... arises precisely from its place within the 'we.""7 Thus, proper moral communication is discussion rather than lecture or negotiation, a "communicative inquiry with a social basis." 8 (Emphasis in original)

The three papers in this issue, as all good writing does, ask the reader to engage in precisely this type of discussion, an honest examination of the reader's own beliefs. In fact, van der Sluijs takes dialogue as a main theme of his paper; what, he asks, can the homeless teach the church about the way it carries out its Christian mission? Likewise, the concluding section of Van Tiem's paper asks the reader to think about how the reader's own behavior contributes to Amazon's status as empire, and the consequences of that: substandard wages for thousand, oppression of competitors, and so forth. Finally, Conway asks whether we are willing to surrender the illusion that our juvenile justice systems have a Minority Report ${ }^{9}$ level of predictive capacity, an illusion that, Conway argues, may close off the possibilities for change and redemption.

If we listen closely, the three papers, even with their very different topics, talk to each other. Van Tiem's definition of empire includes an element of coercion; empires attempt to determine how we live, in Amazon's case based on algorithmic predictions of our preferences. Conway's actuarial justice attempts to do precisely the same thing for juveniles finding themselves in the justice system; the system says, in effect, that we know your future desires and will attempt to control them. Conway and van der Sluijs's papers share a quality of theological reversal, using theology to ask potentially subversive questions. We typically think of the criminal justice system as a way of protecting social interests. Suggesting, as Moltmann might, that the need is for community self-sacrifice to promote individual redemption is out of the box thinking by any measure. Van der Sluijs is equally provocative. Many writers have considered at length what our

${ }_{6}^{5}$ Grand Rapids: Eerdmans, 2013.

6 "Bear one another's burdens, and so fulfil the law of Christ. For if any one thinks he is something, when he is nothing, he deceives himself. But let each one test his own work, and then his reason to boast will be in himself alone and not in his neighbor. For each man will have to bear his own load." Gal 6:2-5 (RSV)

${ }^{7}$ O'Donovan, Self, World, and Time, 43.

${ }^{8}$ Id

${ }^{9}$ A 2002 Steven Spielberg film, starring Tom Cruise, based on the premise that human predictive capability would one day allow law enforcement to arrest persons for crimes they had not yet committed. 
treatment of the poor has to say about us. Van der Sluijs's flips the inquiry: what do the "homeless" have to say about the rest of us? Both challenge the way in which social labels - homeless or problem youth - become both restrictive and self-fulfilling.

All three papers call us to think about the concept of time, also central to O'Donovan's moral vision. The concerns over data-driven legal or commercial decision-making are inherently temporal, grounded in a belief that knowledge of the past and present can predict the future. And, as van der Sluijs points out, much of our social policy regarding homelessness is grounded in a definition of "homeless" that is out of date and would be disputed by the very persons classified as homeless. Indeed, as the paper points out, we define homelessness in such a way as to make it a condition to be remedied in service of a better future, ignoring how in many cases it is also an escape from an oppressive past. O'Donovan points out as we decide what is to be done in the present, and it is only in the present that we can act, the past event supremely important is the resurrection, and the future event towards which all present actions should point is the redemption of creation.

Finally, all three ask us to consider the underlying cost of what in many ways constitute social goods: well-intentioned efforts to confront homelessness, increased access to commodities that provided a lifeline to many during the pandemic, and management through the justice system of seriously troubled youth. This type of dialogue is at the heart of moral inquiry, and of the ethical life: theological ethics in particular, as we are asked to face Jesus's piercing question: "who do you say I am?” The School of Divinity is proud to provide the platform for the discussion.

Daniel Rentfro Jr. Managing Editor

Advent 2021 